\title{
Kesesuaian Pemeriksaan Aglutinasi Lateks Dengan BTA Mikroskopis untuk Mengidentifikasi Pasien Tuberkulosis
}

\author{
Prima O. Damhuri ${ }^{1}$, Netti Suharti ${ }^{2}$, Efrida $^{3}$, Masrul Basyar ${ }^{4}$, Andani E. Putra $^{2}$
}

\begin{abstract}
Abstrak
Pemeriksaan aglutinasi merupakan teknik pemeriksaan yang sederhana, cepat, murah, dan tidak memerlukan keahlian kusus dalam pemeriksaannya. Uji aglutinasi lateks merupakan suatu pemeriksaan berdasarkan reaksi aglutinasi yang terbentuk akibat interaksi antara antigen dan antibodi. Pemeriksaan yang paling sering dilakukan dilaboratorium kesehatan untuk mengidentifikasi Mycobacterium tuberculosis adalah pemeriksaan Bakteri Tahan Asam (BTA) mikroskopis. Tujuan: Mengetahui kesesuaian antara pemeriksaan aglutinasi lateks dan pemeriksaan BTA mikroskopis untuk mengidentifikasi pasien tuberkulosis. Metode: Penelitian ini merupakan uji diagnostik aglutinasi lateks menggunakan antibodi poliklonal dengan rangcangan crossectional. Pemeriksaan dilakukan terhadap 100 orang pasien suspek tuberkulosis di Laboratorium Mikrobiologi Fakultas Kedokteran Universitas Andalas dari Januari 2018 sampai dengan Januari 2019. Sampel sputum direaksikan dengan reagen lateks dan diamati ada tidaknya terbentuk. Kesesuaian pemeriksaan uji aglutinasi lateks dibandingkan dengan pemeriksaan BTA mikroskopis. Hasil: Nilai koefisien kappa sebesar 0,473 $(p=0,000)$ menunjukkan kesepatan antara pemeriksaan aglutinasi lateks dan BTA mikroskopis cukup $(k 0,41$ 0,60). Simpulan: Uji aglutinasi lateks dengan pemeriksaan BTA mikroskopis untuk mengidentifikasi pasien tuberkulosis pada sampel sputum memiliki nilai kesepakatan yang cukup.
\end{abstract}

Kata kunci: aglutinasi, tuberkulosis, bakteri tahan asam, mikroskopis

\section{Abstract}

Agglutination test is a simple, fast, cheap, examination technique does not require special expertise. Latex agglutination test is an examination based on the agglutination reaction formed by the interaction between antigens and antibodies. The most frequently performed examination in a health laboratory to identify Mycobacterium tuberculosis is microscopic smear examination. Objectives: To determined the suitability of latex agglutination examination with microscopic smear examination to identify tuberculosis patients. Methods: This study was a diagnostic test of latex agglutination used polyclonal antibodies with crossectional design. The examination was carried out on 100 patients with suspected tuberculosis in the Laboratory of Microbiology, Faculty of Medicine Andalas University from January in 2018 until January in 2019. Sputum samples were reacted with latex reagents and observed whether or not they were formed. The suitability of the latex agglutination test is compared with that of microscopic AFB. Results: The kappa coefficient of $0.473(p=0.000)$ indicating the accuracy between the examination of latex agglutination and microscopic smear was moderate ( $k$ 0.41-0.60). Conclusion: The latex agglutination test and microscopic smear examination to identify tuberculosis patients in the sputum sample having moderate agreement value.

Keywords: agglutination, tuberculosis, acid fast bacill, microscopis

Affiliasi penulis: 1. Stikes Syedza Saintika, Padang, Indonesia 2. Bagian Mikrobiologi, Fakultas Kedokteran, Universitas Andalas, Padang, Indonesia. 3. Bagian Patologi Klinik, Fakultas Kedokteran, Universitas Andalas, Padang, Indonesia 4. Bagian Pulmonologi, Fakultas Kedokteran, Universitas Andalas, Padang, Indonesia
Korespondensi: Andani Eka Putra

Email:andani1508@med.unand.ac.id Telp: 081226954302 


\section{PENDAHULUAN}

Tuberkulosis paru adalah penyakit infeksi kronis dan menular yang disebabkan oleh Mycobacterium tuberculosis, Mycobacterium bovis, Mycobacterium leprae, tetapi mayoritas disebabkan oleh Mycobacterium tuberculosis. ${ }^{1}$ Tuberkulosis menempati peringkat kesembilan sebagai penyebab utama kematian oleh penyakit menular di dunia setelah infeksi Human immunodeficiency Virus (HIV). ${ }^{2}$ Sebanyak 6,3 juta orang terinfeksi tuberkulosis pada tahun 2016 (naik dari 6,1 juta di tahun 2015). Jumlah penderita tuberkulosis di Indonesia menduduki peringkat ke-2 terbanyak di dunia setelah India. ${ }^{2}$ Pada tahun 2015 terjadi peningkatan jumlah kasus baru dengan basil tahan asam (BTA) positif yaitu sebesar 117 per 100.000 penduduk. $^{3}$

Diagnosis dini tuberkulosis memiliki peranan penting dalam mengurangi risiko penularan penyakit. diagnostik pasti tuberkulosis adalah dengan menggunakan pemeriksaan kultur dan mengidentifikasi organisme. Pemeriksaan tuberkulosis yang biasanya dilakukan di laboratorium, baik di puskesmas maupun rumah sakit adalah dengan teknik mikroskopis BTA pada sputum dan kultur sebagai konfirmasi diagnosis laboratorium. Pemeriksaan basil tahan asam merupakan pemeriksaan yang sederhana, murah, cepat, praktis, dan merupakan salah satu jenis pemeriksaan yang sering digunakan di negaranegara berkembang. ${ }^{4}$

Pemeriksaan BTA mikroskopis memiliki nilai sensitivitas yang rendah, akan tetapi nilai spesifisitas pemeriksaan BTA konsentrasi sangat tinggi. Nilai spesifisitas yang tinggi menandakan pemeriksaan BTA mikroskopis dapat mendeteksi tuberkulosis pada orang yang sakit sangat tinggi. Mathew et al. (2002) mengemukakan nilai sensitivitas dan spesifisitas pemeriksaan BTA mikroskopis yang dilakukan terhadap 3556 pasien suspek tuberkulosis di dua rumah sakit adalah $67,5 \%$ dan $97,5 \% .^{5}$

Nausheen et al. (2016) mengemukakan akurasi pemeriksaan BTA mikroskopis adalah sebesar $92,85 \%$ dengan nilai sensitivitas dan spesifisitas pemeriksaan BTA sebesar $63,63 \%$ dan $97,26 \%{ }^{6}$

Aglutinasi lateks (menggunakan partikel lateks) telah banyak digunakan di laboratorium klinik kesehatan. Pemeriksaan metode aglutinasi lateks merupakan salah suatu metode pemeriksaan cepat dan dapat digunakan pada berbagai bidang. Pemeriksaan aglutinasi lateks merupakan pemeriksaan yang sederhana, murah, cepat, tidak memerlukan peralatan khusus dan keterampilan khusus pada pemeriksaannya. Uji aglutinasi lateks berdasarkan reaksi aglutinasi antara antigen dan antibodi yang diikatkan pada partikel lateks. ${ }^{7,8}$

Nilai sensitivitas dan spesifisitas pemeriksaan aglutinasi lateks cukup baik. Pemeriksaan aglutinasi menggunakan metoda aglutinasi liposomal mendapatkan nilai sensitivitas dan spesifisitas sebesar $97,8 \%$ dan $95,7 \%$. Bhaskar et al. juga mengemukakan nilai sensitivitas dan spesifisitas dari uji aglutinasi lateks adalah $94 \%$ dan 92,2\% pada tuberkulosis paru, sedangkan sensitivitas tuberkulosis ekstra paru adalah $87 \% .^{9}$

Berdasarkan hal tersebut penulis tertarik untuk mengetahui kesesuaian pemeriksaan aglutinasi lateks dengan BTA mikroskopis untuk mengidentifikasi pasien tuberkulosis.

\section{METODE}

Penelitian ini adalah penelitian eksperimental dengan desain cross sectional yang dilakukan di laboratorium Mikrobiologi Fakultas Kedokteran UNAND untuk uji aglutinasi, pengambilan isolat Mycobacterium tuberculosis dilakukan di RS Paru Provinsi Sumatera Barat dari Januari 2018 sampai dengan Januari 2019.

\section{Pembuatan Reagen Lateks, Sensitisasi Partikel Lateks}

Serum yang mengandung antibodi poliklonal diencerkan dengan konsentrasi 5\%. Polystiren latex beads (LB 8 Sigma aldrich) diencerkan dengan konsentrasi $0,625 \%$. Sebanyak $125 \mu \mathrm{l}$ serum antibodi poliklonal ditambahkan dengan lateks beads hingga volume total $600 \mu \mathrm{l}$. Campuran larutan kemudian diinkubasi pada suhu ruang 
selama 1 jam. Lateks beads dicuci dengan GBS yang mengandung BSA $0,1 \%$ sebanyak 2 kali. Kemudian disentrifus dengan kecepatan 5000 rpm selama 4 menit pada suhu $4^{\circ} \mathrm{C}$. Lateks beads disuspensikan dengan 540 GBS-BSA, tambahkan $60 \mu \mathrm{l}$ GBS yang mengandung FBS 25\%. Reagen lateks dapat disimpan pada suhu $4^{\circ} \mathrm{C}$.

\section{Pemeriksaan Aglutinasi Lateks pada Sampel Sputum}

Pemeriksaan aglutinasi lateks dilakukan dengan memipet $50 \mu \mathrm{l}$ sampel tambahkan $10 \mu \mathrm{l}$ suspensi pereaksi lateks kedalam. Campuran diaduk atau digoyang kemudian baca hasil. Hasil positif ditandai dengan terbentuknya aglutinasi.

\section{HASIL}

Sampel penelitian yang digunakan adalah sampel sputum pasien suspek tuberkulosis yang melakukan pemeriksaan kultur di Rumah Sakit Paru Provinsi Sumatera Barat. Besar sampel yang digunakan pada penelitian adalah 100 sampel yang terdiri atas, 70 orang (70\%) laki-laki dan 30 orang (30\%) perempuan.

Tabel 1. Perbandingan hasil pemeriksaan aglutinasi lateks dengan BTA mikroskopis

\begin{tabular}{lllll}
\hline Metode & & \multicolumn{3}{c}{ BTA Mlkroskopis } \\
\cline { 3 - 5 } & & Positif & Negatif & Total \\
\hline Aglutinasi & Positif & 23 & 13 & 36 \\
lateks & Negatif & 11 & 53 & 64 \\
& Total & 34 & 66 & 100 \\
\hline
\end{tabular}

Hasil penelitian terhadap uji aglutinasi lateks dan BTA dari 100 sampel didapatkan sebanyak 53 sampel negatif dan 23 sampel positif. Sementara itu, Pada hasil pemeriksaan BTA negatif didapatkan sebanyak 13 sampel hasil positif pada uji aglutinasi dan pada BTA positif didapatkan sebanyak 11 sampel negatif pada uji aglutinasi. Analisa statistik dengan uji Kappa menunjukkan ada hubungan antara aglutinasi lateks dan BTA dengan tingkat kesesuaian 0,473 ( $p=0.000)$.

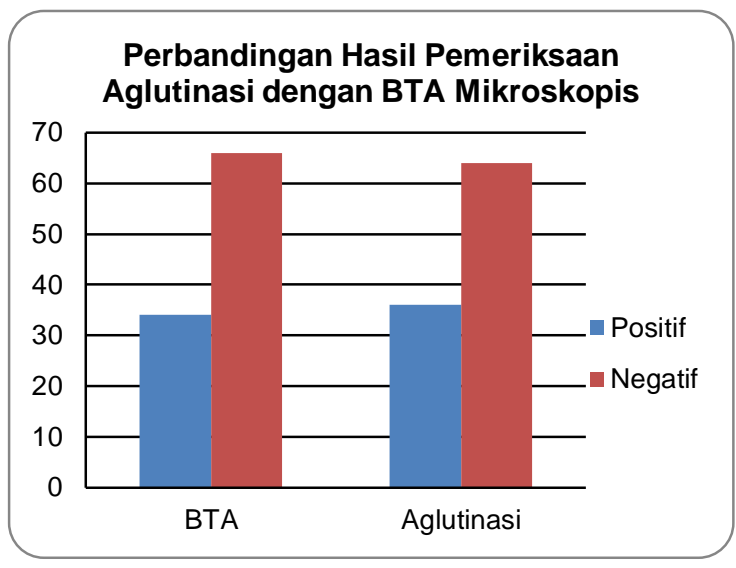

Gambar 1. Perbandingan hasil pemeriksaan aglutinasi dengan BTA

\section{PEMBAHASAN}

Angka kejadian tuberkulosis paling sering terjadi pada laki-laki dibandingkan dengan perempuan. ${ }^{10}$ Studi meta-analisis yang dilakukan Horton et al terhadap 28 negara juga memberikan bukti yang kuat bahwa prevalensi tuberkulosis lebih tinggi terjadi pada laki-laki dibandingkan dengan perempuan. ${ }^{11} \mathrm{Hal}$ ini juga didukung oleh Rao yang menyatakan rasio antara laki-laki dan perempuan yang terinfeksi tuberkulosis adalah 2:1.10 Survei yang dilakukan terhadap 308 orang laki-laki didapatkan 248 orang diantaranya positif terinfeksi tuberkulosis yang dikonfirmasi dengan BTA positif dan dari 138 orang perempuan yang diperiksa, didapatkan sebanyak 116 orang yang menderita tuberkulosis positif. ${ }^{12}$

Kasus tuberkulosis paru terbanyak terjadi pada laki-laki dibandingkan dengan perempuan. Hal tersebut dapat disebabkan karena faktor risiko lakilaki lebih tinggi dibandingkan dengan perempuan. Laki-laki pada umumnya memiliki aktivitas yang lebih tinggi terutama diluar ruangan dibandingkan perempuan. Hal tersebut menyebabkan peluang kontak dengan orang yang terinfeksi tuberkulosis menjadi semakin lebih tinggi. ${ }^{13,14}$

Kebiasaan merokok dan paparan asap rokok juga menjadi salah satu faktor risiko yang dapat meningkatkan risiko infeksi tuberkulosis, tuberkulosis aktif dan kematian akibat tuberkulosis 
yang disebabkan penurunan daya tahan tubuh. ${ }^{14,15}$ Penelitian Muchtar et al. (2018) menunjukkan sebanyak 40 responden $(61,5 \%)$ pasien tuberkulosis memiliki riwayat merokok, sebagian besar merupakan former smoker (mantan perokok) dengan persentase $60 \% .^{14}$

Hasil penelitian terhadap uji aglutinasi lateks dan BTA dari 100 sampel didapatkan sebanyak 53 sampel negatif dan 23 sampel positif. Sementara itu, Pada hasil pemeriksaan BTA negatif didapatkan sebanyak 13 sampel hasil positif pada uji aglutinasi dan pada BTA positif didapatkan sebanyak 11 sampel negatif pada uji aglutinasi. Analisa statistik dengan uji Kappa menunjukkan ada hubungan antara aglutinasi lateks dan BTA dengan tingkat kesesuaian $0,473(p=0.000)$.

Penelitian ini mendapatkan hasil terdapat kesesuaian antara pemeriksaan aglutinasi lateks dengan BTA mikroskopis dengan nilai Kappa 0,473. Berdasarkan skala Altman nilai Kappa 0,473 menandakan bahwa tingkat kesepakatan pemeriksaan aglutinasi lateks dengan BTA mikroskopis dalam kategori cukup $(0,41-0,60) .{ }^{16}$

Pemeriksaan dengan metode aglutinasi juga lebih murah dan mudah untuk diterapkan dilaboratorium terutama pada daerah-daerah yang baru berkembang. Pemeriksaan ini juga tidak memerlukan keterampilan khusus sehingga dapat diaplikasikan secara luas dan merupakan suatu metoda yang dapat dipertimbangakan sebagai salah satu alternatif pemeriksaan TB. ${ }^{17}$

Pemeriksaan aglutinasi lateks merupakan salah satu pemeriksaan immunodiagnostik yang sederhana, lebih ekonomis, dapat diaplikasikan secara luas, tidak membutuhkan peralatan khusus dalam pemeriksaannya, cepat, hasil tes yang jelas dan mudah dibaca. Pemeriksaan aglutinasi berdasarkan pada prinsip interaksi antara antigen dengan antibodi atau sebaliknya sehingga terbentuk kompleks antigen antibodi. Metode pemeriksaan teknik aglutinasi lateks dapat dijadikan sebagai salah satu metode alternatif untuk mengidentifikasi antigen Mycobacterium tuberculosis pada cairan tubuh. ${ }^{18}$
Penelitian ini mendapatkan 15 sampel memiliki hasil yang berbeda dengan hasil kultur yang terdiri atas 13 sampel menunjukkan hasil positif palsu dan sebanyak 2 sampel menunjukan hasil negatif palsu. Positif palsu dapat disebabkan karena komponen yang ada di dalam serum yang digunakan untuk dicoating dengan partikel lateks tidak hanya antibodi terhadap Mycobacterium, tetapi kemungkinan besar didalam serum juga mengandung antibodi terhadap antigen lainnya. ${ }^{19}$ Sampel klinis yang digunakan seperti sputum juga memiliki risiko tinggi terjadinya reaksi silang, hal ini dapat disebabkan karena sputum mengandung komponen lain yang dapat membentuk kompleks imun sehingga menyebabkan suatu pemeriksaan menjadi tidak spesifik. ${ }^{20}$

Keterbatasan dari pemeriksaan ini adalah penggunaan serum kelinci yang belum dimurnikan dari bahan-bahan lain yang akan mempengaruhi reaksi aglutinasi yang kemungkinan dapat menyebabkan suatu pemeriksaan menjadi kurang spesifik.

\section{SIMPULAN}

Penelitian ini mendapatkan hasil terdapat kesesuaian antara pemeriksaan aglutinasi lateks dengan BTA mikroskopis dengan nilai Kappa 0,473. Berdasarkan skala Altman nilai Kappa 0,473 menandakan bahwa tingkat kesepakatan pemeriksaan aglutinasi lateks dengan BTA mikroskopis dalam kategori cukup $(0,41-0,60)$.

\section{SARAN}

Serum kelinci yang digunakan untuk dicoating partikel lateks pada uji aglutinasi lateks sebaiknya dimurnikan terlebih dahulu dari bahanbahan yang mempengaruhi reaksi aglutinasi sehingga hasil pemeriksaan menjadi lebih akurat. Pemurnian antibodi biasanya dengan menggunakan polietilen glikol (PEG) atau amonium sulfat dan untuk melihat kemurnian antibodi dilakukan dengan SDS-PAGE. Untuk mengetahui jumlah optimal antibodi yang dapat digunakan pada uji aglutinasi untuk dicoating dengan partikel lateks 
dilakukan pengukuran kadar antibodi dengan menggunakan spektrofotometer.

\section{UCAPAN TERIMA KASIH}

Terima kasih yang sebesar-besarnya untuk seluruh pihak yang turut membantu dalam penelitian ini.

\section{DAFTAR PUSTAKA}

1. Brooks GF, Karen CC, Janet SB, Stephen AM, Timothy AM, Jawetz, et al. Mikrobiologi kedokteran. Nugroho AW, penerjemah; Adityaputri A penyunting. Penerbit Buku Kedokteran: EGC. 2010.

2. World Health Organization (WHO). Global Tuberculosis Report. Geneva: World Health Organization; 2017. hlm 1-3.

3. Kemenkes RI. Tuberkulosis temukan obat sampai sembuh. Jakarta: Kemenkes RI; 2016. hlm 154-156.

4. Bhirud P, Joshi A, Hirani N, Chowdhary A. Rapid laboratory diagnosis of pulmonary tuberculosis. International Journal of Mycobacteriology. 2017; 6:296-301.

5. Mathew P, Yen-Hong K, Bindu V, Robert HKE, Melvin. Are three sputum acid fast bacillus smears necessary for discontinuing tuberculosis isolation? Journal of Clinical Microbiology. 2002; 40(9):3482-4.

6. Nausheen S, Naseem A, Saifullah B, Nadeem R. To compare the diagnostic accuracy of acid fast bacilli smear results of induced sputum with broncho alveolar lavage among pulmonary tuberculosis cases kepping acid fast bacilli culture as gold standard in a resource limited setting in non expectorating patients. European Respiratory Journal. 2016; 48(suppl 60): PA2774.

7. Carney J. Rapid diagnostic tests employing latex particles. In Analytical Proceedings. 1990;27:99100.

8. Mahat M, Abdullah WZ, Hussin C, Maraina C. Conventional rapid latex agglutination in estimation of Von Willebrand Factor: method revisited and potential clinical applications. Journal of immunology research. 2014:10.

9. Bhaskar S, Banavaliker JN, Hanif M. Large-scale validation of a latex agglutination test for diagnosis of tuberculosis. FEMS Immunology and Medical Microbiology. 2003;39(3):235-9.

10.Rao S. Tuberculosis and patient gender: an analysis and its implications in tuberculosis control. Journal of Lung India. 2009;26(2):46.

11. Horton KC, MacPherson P, Houben RM, White $R G$, Corbett EL. Sex differences in tuberculosis burden and notifications in low-and middleincome countries: a systematic review and meta-analysis. Plos Medicine. 2016; 13 (9): e1002119.

12.Kemenkes RI. Profil kesehatan Indonesia tahun 2015. Jakarta: Kemenkes RI. 2016.

13.Andayani S, Astuti Y. Prediksi kejadian penyakit tuberkulosis paru berdasarkan usia di kabupaten Ponorogo tahun 2016-2020. Indonesian Journal for Health Sciences. 2017; 1(2):29-33.

14. Muchtar NH, Herman D, Yulistini. Gambaran faktor risiko timbulnya tuberkulosis paru pada pasien yang berkunjung ke unit DOTS RSUP Dr. M. Djamil Padang tahun 2015. Jurnal Kesehatan Andalas. 2018;7(1):80-7.

15.Silva DR, Marcela MT, Raquel D, Tatiana G, Eduardo HB, Flavio FA, et al. Risk factors for tuberculosis: diabetes, smoking, alcohol use, and the use of other drugs. Jornal Brasileiro de Pneumologia. 2018;44(2):145-52.

16.Putra WGA, Sutarga M, Kardiwinata MP, Suariyani NLP, Septriani W, Subrata M. Modul penelitian uji diagnostik dan skrining. Denpasar. Prodi Kesehatan Masyarakat, Fakultas Kedokteran, Universitas Udayana; 2016. hlm. 36.

17. Shenoy B, Biradar S. Latex agglutination test (LAT) for rapid diagnosis of acute bacterial meningitis. Journal of Pediatric Infectious Disease. 2014;6(4):150-2.

18.Chan EC, Yang MY. Method for detection of mycobacterium tuberculosis antigens in 
biological fluid. US Patent Application No. 10/862,748. 2005.

19.Dai Z, Liu Z, Xiu B, Yang X, Zhao P, Zhang X, et al. A Multiple-antigen detection assay for tuberculosis diagnosis based on broadly reactive polyclonal antibodies. Iranian Journal of
Basic Medical Sciences. 2017;20(4):360.

20.Arias-Bouda LMP, Nguyen LN, Ho LM, Kuijper $\mathrm{S}$, Jansen HM, Kolk $\mathrm{AH}$. Development of antigen detection assay for diagnosis of tuberculosis using sputum samples. Journal of Clinical Microbiology. 2000;38(6):2278-83. 